$\begin{array}{lllll}\text { 中 島 重 } & \text { 義 }^{\dagger} \text {, 正会員 濱 } & \text { 裕 } \text { 光 }^{\dagger} \\ \text { 前 川 義 } & \text { 治 }^{\dagger}, & \text { 細 } & \text { 省 } \text { 一 }^{\dagger}\end{array}$

\title{
Elliptical Approximation of Trajectories of a Moving Object
}

\author{
Shigeyoshi Nakajima ${ }^{\dagger}$, Hiromitsu Hama ${ }^{\dagger}$, Yoshiharu Maekawa ${ }^{\dagger}$ and Shouichi Hosokawa ${ }^{\dagger}$
}

あらまし 動画像の中の回転物体の特徵点の軌跡を解析するために, 時空間中で楕円近似する方 法について提案する．時空間で解析するため, 画像平面上よりもグループ化が容易である. シミュ レーションにより時空間上の楕円軌跡を高い精度で近似できることを確認した。

\section{1. まえがき}

動画像中の動物体の特徵点の軌跡を追跡すること は, 3 次元シーンの復元には大変有用なことであ る ${ }^{1) ~ 3)}$. 筆者らは動画像中の特徵点の速度と位置から 3 次元空間の物体の構造を復元する手法を提案した が4)，そこでも速度と位置を正確に算出するためには 特徵点の軌跡を高次元の曲線で近似する必要があるこ とがわかった。

物体の回転運動には，固定した回転軸のまわりの運 動と，移動する回転軸のまわりの運動とがある．回転 軸の位置が固定されていると考え得るとき，特徵点の 軌跡が円錐曲線を描くことが知られている5)。そのよ うな円錐曲線の中でも，軌跡のすべてが視野に入って いるような場合には画像平面上で楕円を描く。この楕 円は, 画像平面と時間変化の 3 次元時空間上では螺旋 になる。この時，空間上の螺旋をまず直線セグメント として近似し，次に直線セグメントと螺旋との中間段 階として棈円近似を求める手法を本論文で提案する. 直線セグメントを検出する手法は筆者らがすでに発表 した手法に従う ${ }^{6)}$.

直線セグメントによる近似から出発し, 螺旋近似す るまでの間で 3 次元時空間上の棈円で近似する利点は 次の点にある.まず, $x-y$ 平面で軌跡を追跡するよ りも時間的なずれを利用する方がグループ化が容易に
なる，次に，直線セグメントから棈円への近似では決 定すべきパラメータが少なく，推定が容易である。さ らに, 楕円近似では軌跡の曲率変化に対応できる。最 後に, 棈円近似を行い, その軌跡を $x-y$ 平面に投射 したときはまた楕円になるので, 螺旋を $x-y$ 平面に 投射したときの棈円をうまく近似できる。このように 時空間上での楕円近似は動画像の観測点の軌跡を求め るのに有用である.

\section{2. 直線セグメントから楕円近似へ}

\section{1 直線セグメントに最も近い平面}

まず，最初に時空間上の観測点列から微小時間内の 直線セグメントを求める。次に, 得られた直線セグメ ントを 4 本集めた組を作る。最小 2 乗法により，この 直線セグメントの両端点から一番近い平面を求める. この平面上に観測された特徴点を正射影し, この平面 上で以下の処理を行う.

\section{2 棈円の中心の推定}

直線セグメントの組の中で上記の平面と両端点の距 離が小さいものを選ぶ. 選ばれた直線セグメントの組 から棈円の中心の位置を推定する。直線セグメントを 楕円の接線と考え, その中点を楕円との接点と考元 る。このとき，直線セグメントを 2 本選んで， 2 接点 の中点, 2 接線を延長した交点, 楕円の中心の 3 点は 図 1 に示すように同一直線上に並ぶ。このことより，

キーワード：単眼視動画像, 動きからの形，3 次元認識

1995 年 4 月 17 日受付, 1995 年 6 月 2 日再受付

$\dagger$ 大阪市立大学 工学部（干 558 大阪市住吉区杉本 3-3-138, TEL 06-605-2684)

$\dagger$ Department of Engineering, Osaka City University (3-3-138, Sugimoto, Sumiyoshi-ku, Osaka 558, Japan) 
2 接点の中点と 2 接線の交点を結んだ直線上に楕円の 中心があると推定できる，4 本の直線セグメントから 2 直線セグメントの組は 6 組でき，それぞれの組に上 述の直線が 1 本存在する。このようにして得られた 6 本の直線に一番近い点を楕円の中心と推定する．6本 の直線に一番近い点は最小 2 乗法によって決定する。

\section{3 楕円の半径，離心率，長軸方向の推定}

前述の平面において推定した楕円の中心を原点と し, 観測された $i$ 番目の特徴点からこの平面におろし た垂線の足の極座標表示を $\left(r_{i}, \theta_{i}\right)$ とする.ただし， 添え字の $i$ に関して $\theta_{i}$ は昇順となるように並べ替え てある。 $r_{i}$ に関して近傍 9 点の平均を取る平滑化を 2 回行い, その結果を $R_{i}$ とする。この点列は棈円の 点列であるが， $R_{i}$ を $\theta_{i}$ に関する次のような余弦関数 で近似する。

$$
R_{i}=R+k \cos 2\left(\theta_{i}-\theta\right)
$$

ここで，定数 $\theta$ は $x$ 軸に対して長軸がなす角を表す. $k$ は離心率に従って単調増加する係数である。ここ で, 楕円の長軸方向を示す $\theta$ を求める必要はあるが, $k$ の值を求めなくても離心率 $e$ と半径 $r$ が求められ れば楕円が特定できる．添え字 $i$ に従って $\theta_{i}$ に関す る $R_{i}$ の 1 次微分值と 2 次微分值を計算し, $\theta$ の值を 算出する.

$$
\begin{aligned}
& 2\left(\theta_{i}-\theta\right)=\tan ^{-1}\left(\frac{-4 k \sin 2\left(\theta_{i}-\theta\right)}{-4 k \cos 2\left(\theta_{i}-\theta\right)}\right) \\
&=\tan ^{-1}\left(\frac{2 R_{i}^{\prime}}{R_{i}^{\prime \prime}}\right) \\
& \theta=\theta_{i}-\left(\theta_{i}-\theta\right)=\theta_{i}-\frac{1}{2} \tan ^{-1}\left(\frac{2 R_{i}^{\prime}}{R_{i}^{\prime \prime}}\right)
\end{aligned}
$$

ただし

$$
R_{i}^{\prime}=\frac{d R_{i}}{d \theta_{i}}, \quad R_{i}^{\prime \prime}=\frac{d^{2} R_{i}}{d \theta_{i}^{2}}
$$

関数 $\tan ^{-1}()$ を使用する場合, $\alpha=\tan ^{-1}(A)$ に対し

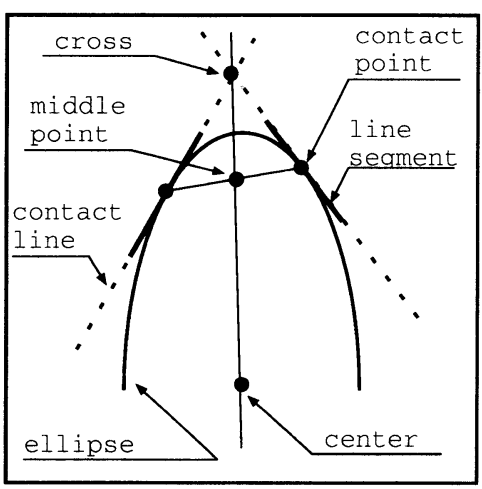

図 13 点が直線に並ぶ The three points are in line.
て, $A=\tan \alpha=\tan (\alpha+\pi)$ となり, 曖昧性が生じる が, 分子 $\left(R_{i}{ }^{\prime}\right)$ と分母 $\left(R_{i}{ }^{\prime \prime}\right)$ の符号を考慮することで $0 \sim 2 \pi$ の範囲で一意的に決めることができる.さらに $0 \sim 4 \pi$ の範囲では 2 解が存在し, 上式を満たす $\theta$ に 対して $\theta+\pi$ も解になるが, どちらを長軸の方向とし ても同一の棈円を得ることができる．実際のデータで は $i$ によって $\theta$ の值が異なるが, すべての $i$ に対し ての分散が最も小さくなる $\theta$ の值を取る.

長軸方向が決定した後, 各観測点ごとに離心率 $e$ と半径 $r$ 関係式ができ,これを $e^{-r}$ 平面上で Hough 変換することで, 最適な $e$ と $r$ が求められ る.

\section{3. 実 験 結 果}

本手法の有効性を示すために計算機シミュレーショ ンを行い，その結果を表 1 に示す。まず，入力として 表 1 に示すパラメー夕を持った楕円の弧を時空間上に 設定し，その楕円に沿って 60 点の観測点を作る. 次 に, 雑音として楕円半径の+10\%から $-10 \%$ の間の一 様擬似乱数による位置ずれを $x$ 方向と $y$ 方向に加え

表 1 計算機シミュレーションによる推定結果 Estimated result of computer simulation.

\begin{tabular}{c|c|c|c|c}
\hline \hline & $\begin{array}{c}\text { もとの值 } \\
\text { (original) }\end{array}$ & $\begin{array}{c}\text { 推定值 } \\
\text { (guessed) }\end{array}$ & $\begin{array}{c}\text { 比率 } \\
\text { (ratio \%) }\end{array}$ & $\begin{array}{c}\text { 誤差 } \\
\text { (error) }\end{array}$ \\
\hline$X_{\text {core }}$ (pixel) & 9.500 & 9.489 & 99.88 & -0.011 \\
\hline$Y_{\text {core }}$ (pixel) & 9.200 & 9.188 & 99.87 & -0.012 \\
\hline$\theta$ (degree) & 9.39 & 12.13 & 129.2 & 2.74 \\
\hline$e$ & 0.600 & 0.609 & 101.5 & 0.009 \\
\hline$r$ (pixel) & 20.00 & 20.14 & 100.7 & 0.14 \\
\hline
\end{tabular}

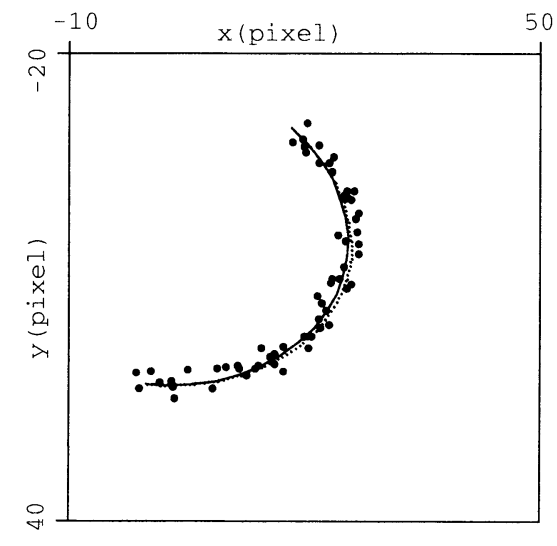

図 2 シミュレーション結果 Simulation result. 
る。これらの点を観測時間別に 4 本の直線で近似した ものを用いた。表 1 より, 中心位置 $\left(X_{\text {core }}, Y_{\text {core }}\right)$ は 高い精度で復元できていることがわかる. 長軸方向 $\theta$ の誤差は $3^{\circ}$ 程度あり, 1 次微分と 2 次微分の誤差の 影響を受けたものと推測される. 離心率 $e$ と半径 $r$ も高い精度で復元できている. 図 2 に，もとの楕円の 弧, 位置ずれを加えた観測点, 復元された楕円の弧を 示す。もとの楕円の弧を実線で，復元された棈円の弧 を点線で示す. 元の楕円と復元された楕円はほとんど 重なっている.

\section{4. むす び}

本稿では, 時空間上での観測点の軌跡を, その直線 近似を利用して時空間上の楕円に近似する手法につい て提案した。時空間上の棈円に沿った観測点の軌跡を 対象とした実験では, 高い精度で楕円のパラメー夕を 復元できることがわかった. 今後は, 実際の動画像上 で観測点が描く螺旋軌跡の復元を, 楕円近似を利用し て効率良く実行する手法について検討する.

大阪市立大学在学中に本研究に協力してくれた中嶋 利和氏（現在，(株)クボタ）に感謝する。

\section{〔参考 文 献〕}

1) T. J. Broida and R. Chellapa: "Estimation of Object Motion Parameters from Noisy Images", IEEE Trans., PAMI-12, 11, pp. 1092-1098 (Nov. 1990)

2) G. Adiv: "Determining Three-Dimensional Motion and Structure from Optical Flow Generated by Several Mov. ing Objects", IEEE Trans., PAMI-7, 4, pp. 384-401 (Apr. 1985)

3) Y. Yasumoto and G. Medioni : "Robust Estimation of Three-Dimensional Motion Parameters from a Sequence of Image Frames Using Regularizations", IEEE Trans., PAMI-8, 4, pp. 464-471 (Apr. 1986)
4) S. Nakajima and H. Hama : "Concentration of Voting by Rotation of Objects in Monocular Moving Image”, Memoirs of the Faculty of Engineering Osaka City Univ., 34, pp. 185-192 (Dec. 1993)

5) H. S. Sawhney, J. Oliensis, and A. R. Hanson: "Image Description and 3-D Reconstruction from Image Trajectories of Rotational Motion", IEEE Trans., PAMI-15, 9, pp. 885-898 (Sep. 1993)

6）杉浦, 中島, 濱：“Hough 変換を用いた動き検出における計 算コストの削減”, 平成 6 年度電気関係学会関西支部連大予, p. G343 (Oct. 1994)

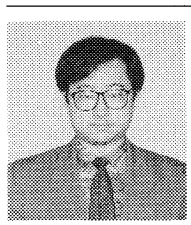

妿㔖島 望義 昭和 62 年, 京都大学大学院 工学研究科電気工学第二専攻博士課程単位取 得満期退学. 同年, 大阪市立大学工学部助 手, 現在に至る。この間, 人工知能, 画像処 理, 並列処理, 神経回路網, コンピュータ・ ビジョンの研究に從事. 工学修士.

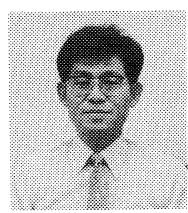

菬裕光昭和 45 年, 大阪大学大学院 基礎工学研究科電気工学専攻修士課程修了. 大阪市立大学工学部電気工学科助手, 情報工 学科助教授を経て, 現在, 同学科教授.この 間, パ夕ーン認識, 変換群不変関数, 画像処 理, 視覚情報処理などの研究に従事. 正会 員.

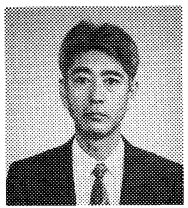

前川竞架義治 昭和 39 年, 大阪市立大学大 学院工学研究科電気工学専攻修士課程修了. 同年, 同大学工学部助手, 43 年, 講師とな り現在に至る。この間, 無機薄膜, 有機薄膜 の合成, 海水の自動計測装置の設計・試作な どに関する研究に従事.

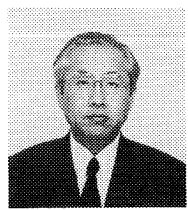

細川省川加昭和 35 年, 大阪市立大学大 学院修士課程修了. 同年, 同大学工学部助 手, 38 年, 同講師, 46 年, 同助教授. 平成 2 年, 同教授 (情報処理工学講座), 現在に至 る.この間, 音声信号の高能率符号化法およ び伝送, 音声認識, コンピュータネットワー ク, ニューラルネットの研究に従事. 工学博 土. 